\title{
Failure to detect specific binding sites for prostaglandin F-2 $\alpha$ in membrane preparations from rat endometrium
}

\author{
D. Martel, T. G. Kennedy*, M. N. Monier and A. Psychoyos \\ Laboratoire de Physiologie de la Reproduction, CNRS ER 203, Hôpital de Bicêtre, Bat. INSERM, \\ 78 Av. du Général Leclerc, 94270 Bicêtre, France
}

\begin{abstract}
Summary. Membrane preparations from endometria of rats in different physiological states (e.g. pseudopregnancy, ovariectomized animals receiving progesterone + oestradiol or oestradiol alone) were studied for $\left[{ }^{3} \mathrm{H}\right] \mathrm{PGF}-2 \alpha$ binding by methods which detected PGF- $2 \alpha$ binding in ovary preparations and PGE binding in the same endometrial preparations. There was no evidence of high-affinity binding sites for $\left[{ }^{3} \mathrm{H}\right] \mathrm{PGF}-2 \alpha$. Saturable $\left[{ }^{3} \mathrm{H}\right] \mathrm{PGF}-2 \alpha$ binding that increased with the onset of uterine sensitivity was detected but this binding does not fulfil all the criteria required for a PGF-2 $\alpha$ receptor and is probably due to binding to PG metabolizing enzymes in our preparations, or to binding of $\left[{ }^{3} \mathrm{H}\right] \mathrm{PGF}-2 \alpha$ to $\mathrm{PGE}$ binding sites.

The failure to detect specific PGF-2 $\alpha$ binding sites seems to reflect a true absence of these sites in the rat endometrium.
\end{abstract}

\section{Introduction}

In rodents, a stimulus from the blastocyst to a sensitive uterine epithelium initiates a rapid process of differentiation in endometrial stroma cells, resulting in the formation of the decidual cells. The uterine sensitivity to the decidualizing stimulus is time-limited and programmed by a strict hormonal sequence (Yochim \& De Feo, 1963; Psychoyos, 1973; Finn, 1977). In ovariectomized animals treated with an appropriate hormonal regimen, a similar reaction can be triggered by a wide variety of stimuli or substances applied to or injected into the uterine lumen (see review by De Feo, 1967).

One of the earliest steps of the implantation process is an increase in vascular permeability in the endometrial area surrounding the blastocyst, as shown by the Evans blue reaction (Psychoyos, 1960). Similarly, an increase in vascular permeability has been shown to precede the decidual cell reaction induced by artificial stimuli. For natural and artificial stimuli, increased vascular permeability is an obligate prerequisite for decidualization (Psychoyos, 1967). It may be that one of the common mechanisms of action of the many different deciduogenic factors could be the liberation by endometrial cells of mediators of the vascular response. Of the several possible mediators, prostaglandins (PGs) have been widely accepted as the most likely. The uterus of pregnant or pseudopregnant rats contains or produces prostaglandins of the series F, E and I (Kennedy \& Zamecnik, 1978; Rankin, Ledfort, Jonsson \& Baggett, 1979; Weems, 1979; Doebler, Wickersham \& Anthony, 1981; Baird, Abel, Brown, Kelly \& Wilmut, 1981; Phillips \& Poyser, 1981; Milligan \& Lytton, 1983). Concentrations of PGE, PGI-2 (measured as 6-keto PGF-1 $\alpha$ ) and also PGF-2 $\alpha$ are elevated in the implantation sites in the rat (Kennedy, 1977; Kennedy \& Zamecnik, 1978) and in the rabbit (Hoffman, Davenport \& Brash, 1984). After the application of a deciduogenic stimulus to a

\footnotetext{
*Present address: MRC Group in Reproductive Biology, University Hospital, University of Western Ontario, 339 Windermere Road, London Ontario, Canada N6A 5 A5.
} 
sensitized uterus, the amounts of prostacyclin (Kennedy, Barke \& Evans, 1980), PGE-2 (Anteby, Bauminger, Zor \& Lindner, 1975; Kennedy, 1979) and PGF-2 $\alpha$ (Rankin et al., 1979; Milligan \& Lytton, 1983) are markedly elevated. Indomethacin, an inhibitor of PG synthesis, prevents the increase in vascular permeability (Kennedy, 1977; Lundkvist \& Nilsson, 1980), decidualization (Castracane, Saksena \& Shaikh, 1974; Tobert, 1976; Rankin et al., 1979) and implantation (Lau, Saksena \& Chang, 1973; Saksena, Lau \& Chang, 1976; El Banna, 1980; Holmes \& Gordashko, 1980). Finally, PGs have been reported to partly overcome the effects of indomethacin and to be effective inducers of decidualization (Saksena et al., 1976; Sananes, Baulieu \& Le Goascogne, 1976; Hoffman, Strong, Davenport \& Frölich, 1977; Kennedy \& Lukash, 1982).

While a role of $\mathrm{PGs}$ as effectors of the increased vasodilatation and vascular permeability that precede implantation has been clearly established, the identity of the PGs implicated remains controversial (Sananes et al., 1976, 1981; Kennedy, 1979; Oettel, Koch, Kurischko \& Schubert, 1979; Kennedy \& Lukash, 1982).

Because the biological effects of PGs are mediated by specific membrane receptors (Rao, 1976), we decided to examine endometrial tissue for these receptors, to elucidate their role as mediators of decidualization. A specific binding site for PGE in membrane preparations of rat endometrium sensitized for the decidual cell reaction has been characterized (Kennedy, Martel \& Psychoyos, $1983 \mathrm{a}, \mathrm{b})$. The aim of the present study was to search for PGF-2 $\alpha$ binding sites in an endometrial membrane preparation of rats sensitized for the decidual cell reaction.

\section{Materials and Methods}

Adult female rats of the Wistar strain, weighing $220-250 \mathrm{~g}$, were housed under control illumination of $14 \mathrm{~h}$ light and $10 \mathrm{~h}$ darkness, with 13:00 h as the midpoint of the light phase.

Pseudopregnant rats. Vaginal smears were recorded daily. After at least two oestrous cycles, pseudopregnancy was induced by vaginal-cervical stimulation on the day of oestrus (De Feo, 1966). The appearance of leucocytes in the vaginal smear on the following day established that day as the first day of pseudopregnancy. The rats were checked daily for the presence of vaginal leucocytes until the day of death.

Rats with a receptive endometrium. Rats ovariectomized for 5-7 days received subcutaneous injections $(0.2 \mathrm{ml})$ of progesterone in sesame oil $(4 \mathrm{mg} /$ day per rat) for 3 days and, on the 4 th day, oestradiol $(0.25 \mu \mathrm{g} / \mathrm{rat})$ was added to the progesterone. The animals were killed $20 \mathrm{~h}$ later, at which time the uterus is in a state of receptivity, and is sensitive to deciduogenic stimuli (Psychoyos, 1967).

Oestrogen-treated rats. Rats ovariectomized for 5-7 days received for 3 days a daily subcutaneous injection of $0.25 \mu \mathrm{g}$ oestradiol/rat. The vehicle was sesame oil. The animals were killed $24 \mathrm{~h}$ after the last injection.

Indomethacin treatment. Indomethacin, $1 \mathrm{mg}$ in $200 \mu \mathrm{l}$ sesame oil, was injected subcutaneously $2 \mathrm{~h}$ before death.

Materials. Radioactive prostaglandins F-2 $\alpha$ and E-2 (sp.act. 150-200 Ci/mmol) were obtained from New England Nuclear Corporation, Boston, MA, U.S.A. Unlabelled PGF-2 $\alpha$, PGE-2, PGE-1, indomethacin and enzymes were purchased from Sigma Chemical Co., St Louis, MO, U.S.A. Other PGs were a gift from Dr J. E. Pike, Upjohn Co., Kalamazoo, MI, U.S.A. Oestradiol and progesterone were a gift from Roussel Uclaf, Romainville, France.

Membrane preparation. Rats were killed by decapitation under ether anaesthesia. The uteri (or ovaries) were rapidly removed by grasping only fat to minimize any trauma-induced stimulation of

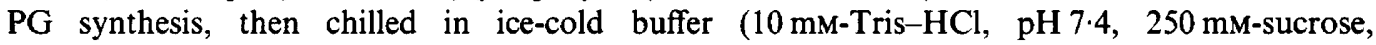
$10 \mu \mathrm{M}$-indomethacin) for at least $1 \mathrm{~min}$. Åll subsequent procedures were carried out at $0^{\circ} \mathrm{C}$ unless 
otherwise specified. Uteri or ovaries were cleaned of connective tissues, the uteri were opened longitudinally and the endometrium was separated from myometrium by gentle scraping (Martel \& Psychoyos, 1978). Tissues were homogenized in buffer ( $1 \mathrm{ml}$ per endometrium or per 2 ovaries) by using a Teflon-glass homogenizer.

Membrane suspensions were prepared as described by Wright, Luborsky-Moore \& Behrman (1979). In summary, the homogenate was centrifuged at $700 \mathrm{~g}$ for $10 \mathrm{~min}$, and the $700 \mathrm{~g}$ supernatant was then centrifuged at $10000 \mathrm{~g}$ for $45 \mathrm{~min}$. The $10000 \mathrm{~g}$ pellet was resuspended in $100 \mathrm{~mm}$-sodium phosphate, $\mathrm{pH} \mathrm{6,100} \mathrm{mM-sucrose,} 10 \mu \mathrm{M}$-indomethacin buffer ( 2 endometria or 4 ovaries $/ \mathrm{ml}$ ), using a Potter-Elvehjem glass-Teflon tissue grinder.

Binding assay. Unless otherwise specified, membrane suspensions were incubated $(\mathrm{v} / \mathrm{v})$ with increasing concentrations of $\left[{ }^{3} \mathrm{H}\right] \mathrm{PGF}-2 \alpha$ or $\left[{ }^{3} \mathrm{H}\right] \mathrm{PGE}-2$ ranging from 4 to $32 \mathrm{~nm}$. In a parallel incubation, a 500-fold excess of unlabelled PGF-2 $\alpha$ (or PGE-2) was added to the radioactivity. The incubation was carried out at $20^{\circ} \mathrm{C}$ for $90 \mathrm{~min}$. The membrane-bound [ $\left.{ }^{3} \mathrm{H}\right] \mathrm{PGF}-2 \alpha$ was separated from the free ligand by filtration ( $100 \mu \mathrm{l}$ incubate) on a millipore filter (HAWP $0.45 \mu \mathrm{m}$ ), and washed twice with $10 \mathrm{ml}$ cold phosphate-sucrose buffer. Assay blanks in which the membrane preparation was replaced by buffer were conducted simultaneously. The filters were counted in a liquid scintillation spectrophotometer. The saturable binding was calculated by subtracting the non-specific binding (unlabelled competitor addition) from the total binding. The results were plotted according to Scatchard (1949).

In one experiment planned to determine the PGF-2 $\alpha$ binding at high concentrations, a fixed concentration of $10 \mathrm{nM}-\left[{ }^{3} \mathrm{H}\right] \mathrm{PGF}-2 \alpha$ (final) was used, with increasing concentrations of PGF- $2 \alpha$ $(0 \cdot 5 \mathrm{~nm}$ to $2 \cdot 5 \mu \mathrm{M}$ final $)$.

Metabolism of $\left[{ }^{3} \mathrm{H}\right] P G F-2 a$. To check for possible metabolism of $\left[{ }^{3} \mathrm{H}\right] \mathrm{PGF}-2 \alpha$, the endometrial membrane preparation was incubated until equilibrium with $10 \mathrm{nM}-\left[{ }^{3} \mathrm{H}\right] \mathrm{PGF}-2 \alpha$ (final concentration). At the end of the incubation, $2 \mu \mathrm{g}$ PGF- $2 \alpha$ were added as a carrier. PGs were then extracted and run on a thin-layer chromatography plate, as described by Kennedy \& Zamecnik (1978). The plates were scraped and the radioactivity counted.

Nature of the $\left.{ }^{3} H\right] P G F-2 a$ binding sites. The membrane preparations were preincubated for $10 \mathrm{~min}$ at $37^{\circ} \mathrm{C}$ with trypsin (Sigma type III, $1 \mathrm{mg} / \mathrm{ml}$ ), trypsin + trypsin inhibitor (Sigma type II-S, $1 \mathrm{mg} / \mathrm{ml}$ ), protease (Sigma type VI from Streptococcus griseus, $1 \mathrm{mg} / \mathrm{ml}$ ), neuraminidase (Sigma type V from Clostridium perfringens, $1 \mathrm{mg} / \mathrm{ml}$ ), phospholipase $\mathrm{C}$ (Sigma type I from Clostridium perfringens, $1 \mathrm{mg} / \mathrm{ml}$ ) or phospholipase A2 (Sigma, from bee venom, $1 \mathrm{mg} / \mathrm{ml}$ ). The membrane preparations were separated from the enzymes by centrifugation at $10000 \mathrm{~g}$ for $45 \mathrm{~min}$, rinsed twice with cold buffer and resuspended for a one-point binding assay. Membranes were incubated with $10 \mathrm{nM}-\left[{ }^{3} \mathrm{H}\right] \mathrm{PGF}-2 \alpha$ with or without $5 \mu \mathrm{M}-\mathrm{PGF}-2 \alpha$.

Protein determinations. The protein concentrations in endometrial membrane preparations were determined according to the method of Lowry, Rosebrough, Farr \& Randall (1951).

Radioactivity determination. Samples or filters were transferred to vials containing $10 \mathrm{ml}$ scintillation fluid (4 g Omnifluor (New England Nuclear) and $36 \mathrm{ml}$ acetic acid per litre toluene). Radioactivity was determined in a liquid scintillation spectrometer (LKB Inst.) and quenching was corrected automatically.

\section{Results}

\section{Association time-course}

A membrane preparation, obtained from a pool of receptive endometria from ovariectomized rats treated with progesterone + oestradiol, was incubated with $10 \mathrm{nM}-\left[{ }^{3} \mathrm{H}\right] \mathrm{PGF}-2 \alpha$ with or 

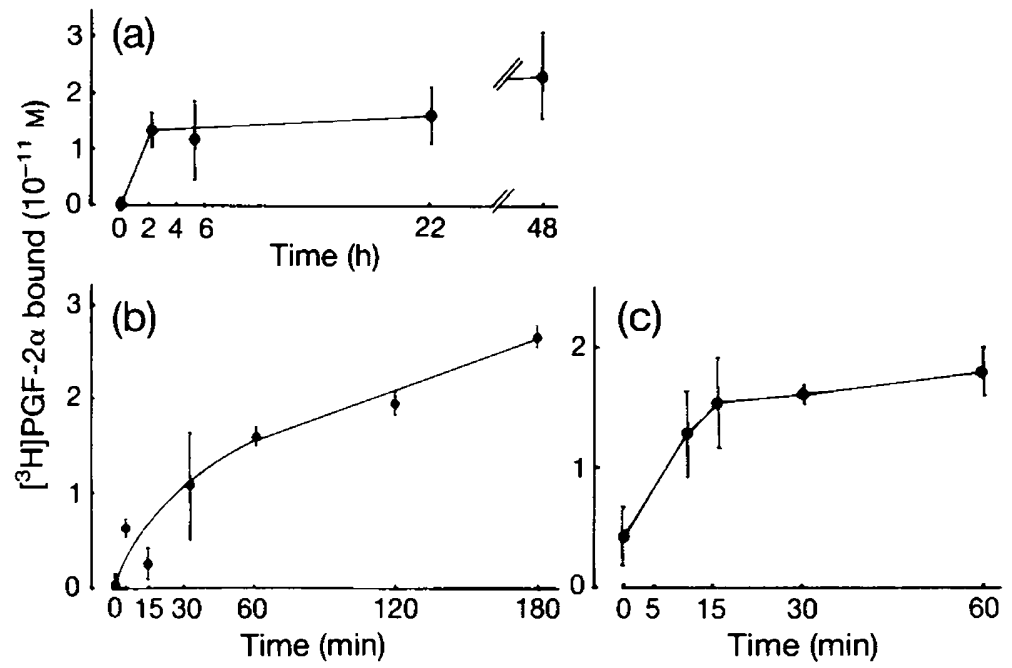

Text-fig. 1. Association time course of $\left[{ }^{3} \mathrm{H}\right] \mathrm{PGF}-2 \alpha, 10 \mathrm{nM}$, at (a) $0^{\circ} \mathrm{C}$, (b) $20^{\circ} \mathrm{C}$, and (c) $37^{\circ} \mathrm{C}$ with a membrane preparation from receptive rat endometrium (ovariectomy plus hormonal treatment). The $\left[{ }^{3} \mathrm{H}\right] \mathrm{PGF}-2 \alpha$ binding (B) $(y$ axis) has been corrected for non-specific binding. Points represent the mean \pm s.e.m. of triplicate determinations.

without $5 \mu \mathrm{M}-\mathrm{PGF}-2 \alpha$ for various periods at 0,20 or $37^{\circ} \mathrm{C}$. Text-figure 1 shows the $\left[{ }^{3} \mathrm{H}\right] \mathrm{PGF}-2 \alpha$ binding after subtraction of the non-saturable binding. The $\left[{ }^{3} \mathrm{H}\right] \mathrm{PGF}-2 \alpha$ binding to the saturable sites was rapid at 20 and $37^{\circ} \mathrm{C}$ compared to $0^{\circ} \mathrm{C}$. An extremely low similar maximal level of binding (44 fmol/mg membrane protein) was reached at each temperature.

\section{Saturation analysis}

Saturation analysis was performed with membrane preparation from receptive endometrium obtained from ovariectomized and hormone-treated rats. The incubations were performed as described in 'Materials and Methods'. The Scatchard plot obtained, after correction for the nonsaturable binding, was a straight horizontal line, indicating that no high-affinity binding was detectable (results not shown). It could be argued that the $\left[{ }^{3} \mathrm{H}\right] \mathrm{PGF}-2 \alpha$ concentrations used were not sufficient to saturate the binding sites. To examine this possibility, an additional saturation analysis was carried out with a fixed concentration of $\left[{ }^{3} \mathrm{H}\right] \mathrm{PGF}-2 \alpha$ and increasing concentrations of unlabelled PGF-2 $\alpha$. Results presented in Text-fig. 2 demonstrate the absence of high-affinity binding under these conditions also. Scatchard plots run at pH 5, 6 or 7 or after addition of 12 mM-thioglycerol to the buffer, also demonstrated no high-affinity binding (results not shown).

To exclude the possibility that the membrane preparation was unsuitable for receptor studies, $\left[{ }^{3} \mathrm{H}\right] \mathrm{PGE}-2$ binding in the uterine membrane preparation was measured simultaneously with PGF- $2 \alpha$ binding and the results are shown in Text-fig. 2. The membrane preparation possessed high-affinity PGE-2 binding sites $\left(K_{\mathrm{d}} 2.5 \mathrm{~nm}\right)$, and a binding capacity of $380 \mathrm{fmol} / \mathrm{mg}$ protein.

It is possible that $\left[{ }^{3} \mathrm{H}\right] \mathrm{PGF}-2 \alpha$ high-affinity sites were undetectable because they were already occupied by endogenous PGF-2 $\alpha$. To examine this hypothesis, ovariectomized animals injected with progesterone + oestradiol were injected subcutaneously with indomethacin (in sesame oil, $1 \mathrm{mg} /$ animal) $2 \mathrm{~h}$ before being killed. The endometrial membranes were incubated with increasing concentrations of $\left[{ }^{3} \mathrm{H}\right] \mathrm{PGF}-2 \alpha$ with or without an excess of PGF-2 $\alpha$. The binding was plotted according to the graphical representation of Scatchard (1949). As previously, a straight horizontal line was obtained, indicating the absence of high-affinity binding sites (not shown). 


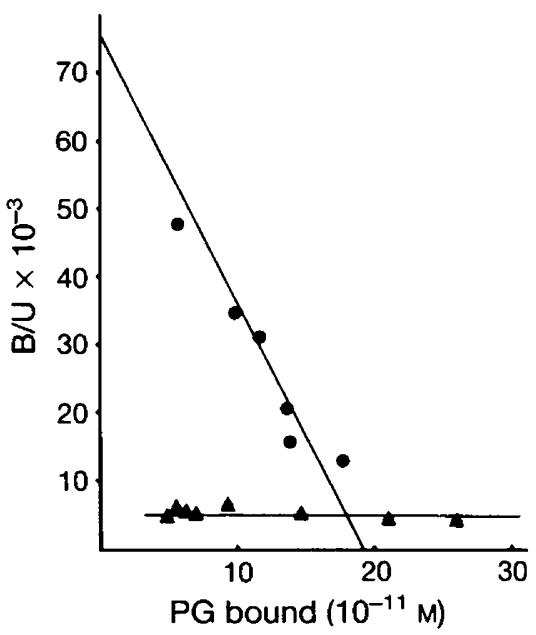

Text-fig. 2. Scatchard plots of the $\left[{ }^{3} \mathrm{H}\right] \mathrm{PGE}-2(\boldsymbol{O})$ and $\left[{ }^{3} \mathrm{H}\right] \mathrm{PGF}-2 \alpha(\Delta)$ binding to a membrane preparation from receptive rat endometrium (ovariectomy plus hormonal treatment). The values have been corrected for non-specific binding measured in a parallel incubation in the presence of an excess of unlabelled PGE-2 or PGF-2 $\alpha$. Points represent the mean of triplicate determinations. On the $y$ axis, $B$ and $U$ represent bound and unbound mediator.

Finally, to demonstrate that the experimental conditions chosen were appropriate to detect PGF- $2 \alpha$ binding sites if present, we determined the concentration of PGF- $2 \alpha$ binding sites in ovarian tissue by using the same assay conditions. The results show that a high-affinity PGF- $2 \alpha$ binding $\left(K_{\mathrm{d}}=7 \mathrm{nM}\right)$ can be detected in ovarian membrane preparations from pro-oestrous and late dioestrous rats (Text-fig. 3). The receptor concentration ( $1000 \mathrm{fmol} / \mathrm{mg}$ protein) as well as the receptor specificity Text-fig. 4) were similar to those previously described for this receptor (Rao, 1976; Wright et al., 1979; Müller, Bauknecht \& Siebers, 1981).

\section{Investigation of $P G F-2 a$ binding in rat endometrium under various hormonal conditions}

For each group, the $\left[{ }^{3} \mathrm{H}\right] \mathrm{PGF}-2 \alpha$ binding was investigated by saturation analysis as described in 'Materials and Methods'. The Scatchard plots resulting were horizontal lines (not shown), indicating no high-affinity binding at Day 1,2,3,4,5 or 6 of pseudopregnancy.

Similarly, endometrial membrane preparations from ovariectomized rats sensitized for the decidual reaction by the sequential injection of progesterone and oestradiol exhibited no highaffinity $\left[{ }^{3} \mathrm{H}\right] \mathrm{PGF}-2 \alpha$ binding. Also, ovariectomized animals treated for 3 days with oestradiol exhibited no high-affinity binding of $\left[{ }^{3} \mathrm{H}\right] \mathrm{PGF}-2 \alpha$.

Although $\left[{ }^{3} \mathrm{H}\right] \mathrm{PGF}-2 \alpha$ high-affinity binding could not be detected by Scatchard analysis under all the conditions tested, there was evidence of a saturable $\left[{ }^{3} \mathrm{H}\right] \mathrm{PGF}-2 \alpha$ binding. This, together with the fact that binding increased gradually with the time and temperature (Text-fig. $1 \mathrm{a}, \mathrm{b}, \mathrm{c}$ ), indicates that saturable $\left[{ }^{3} \mathrm{H}\right] \mathrm{PGF}-2 \alpha$ binding does exist. Table 1 shows the value of this binding, estimated from the highest $\left[{ }^{3} \mathrm{H}\right] \mathrm{PGF}-2 \alpha$ concentration used in the assay. The saturable $\left[{ }^{3} \mathrm{H}\right] \mathrm{PGF}-2 \alpha$ binding was not statistically significantly different (Student's $t$ test) on Day 2, 3 and 4 of pseudopregnancy (around $18 \mathrm{fmol} / \mathrm{mg}$ membrane protein); it then increased on Days 5 and 6 of pseudopregnancy to reach levels of 35 and $40 \mathrm{fmol} / \mathrm{mg}$ membrane protein respectively. There was no statistically significant difference ( $t$ test) between values on Days 5 and 6 of pseudopregnancy. The $\left[{ }^{3} \mathrm{H}\right] \mathrm{PGF}-2 \alpha$ saturable bindings measured on Days 2, 3 or 4 of pseudopregnancy were each statistically significantly different from those measured on Day 5 or 6 (Student's $t$ test: Day 2 vs Day $5, P<0.01$; Day 2 vs 


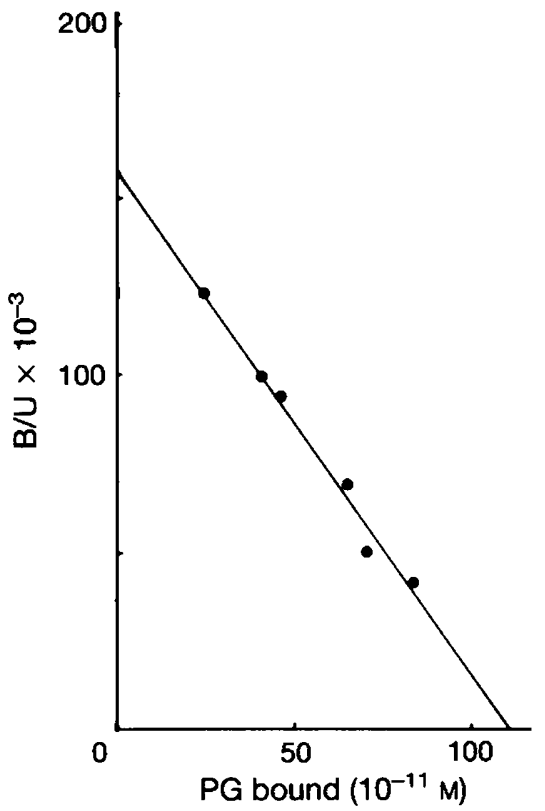

Text-fig. 3. Scatchard plot of the specific $\left[{ }^{3} \mathrm{H}\right] \mathrm{PGF}-2 \alpha$ binding to a membrane preparation from ovaries of rats in late dioestrus or pro-oestrus. Points are means of triplicate determinations.

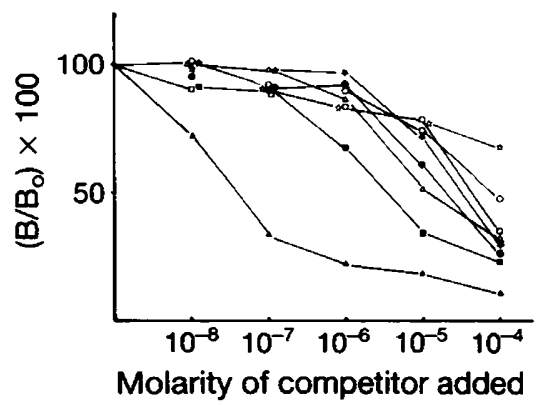

Text-fig. 4. Inhibition of $\left[{ }^{3} \mathrm{H}\right] \mathrm{PGF}-2 \alpha$ binding $\left(B_{\mathrm{o}}\right)$ to a membrane preparation from ovaries of dioestrous or pro-oestrous rats by unlabelled compounds (B): $\mathbf{\Lambda}$, PGF-2 $\alpha ; \mathbf{\square}$, PGE-2; $\triangle$, thromboxane B-2; ๑, 15-keto PGF-2 $\alpha$; , PGE-1; $\square$, arachidonic acid; $O$, PGA-1; is, 15-keto-PGE-2. Points represent the mean of triplicate determinations.

Day 6, $P<0.001$; Day 3 vs Day 5, $P<0.001$; Day 3 vs Day $6, P<0.001$; Day 4 vs Day 5 , $P<0.001$; Day 4 vs Day 6, $P<0.001$ ).

\section{Nature of the $\left[{ }^{3} H\right] P G F-2 a$ binding sites}

To determine the nature of the $\left[{ }^{3} \mathrm{H}\right] \mathrm{PGF}-2 \alpha$ binding sites, endometrial membrane preparations from ovariectomized rats treated with progesterone + oestradiol were incubated with various enzymes. The $\left[{ }^{3} \mathrm{H}\right] \mathrm{PGF}-2 \alpha$ saturable binding (as \% of control, 3 determinations per value) was markedly decreased with all the enzyme treatments (trypsin, 29.8; protease, 19.7; neuraminidase, 54.4; phospholipase A2, 6.9; phospholipase C, 2.1), the loss of binding being almost total after 
Table 1. Saturable $\left[{ }^{3} \mathrm{H}\right] \mathrm{PGF}-2 \alpha$ binding by an endometrial membrane preparation from rats at different hormonal states

\begin{tabular}{lc}
\hline Physiological state & $\begin{array}{c}{\left[{ }^{3} \mathrm{H}\right] \text { PGF-2 } \alpha \text { saturable binding* }} \\
\text { (fmol/mg membrane proteins) }\end{array}$ \\
\hline Pseudopregnant, Day 2 & $16 \cdot 33 \pm 4 \cdot 43$ \\
Pseudopregnant, Day 3 & $16 \cdot 02 \pm 7 \cdot 90$ \\
Pseudopregnant, Day 4 & $17 \cdot 48 \pm 5 \cdot 92$ \\
Pseudopregnant, Day 5 & $35 \cdot 04 \pm 9 \cdot 04$ \\
Pseudopregnant, Day 6 & $39.68 \pm 4 \cdot 80$ \\
Pseudopregnant, Day 5+ & \\
indomethacin in vivo & $38 \cdot 34 \pm 4 \cdot 71$ \\
Ovariectomized + & \\
progesterone + oestradiol & $42 \cdot 00 \pm 5 \cdot 05$ \\
Ovariectomized + oestradiol & $43 \cdot 37 \pm 2 \cdot 77$ \\
\hline
\end{tabular}

*Values are mean \pm s.e.m. for 6 determinations.

Saturable binding was calculated from the highest $\left[{ }^{3} \mathrm{H}\right] \mathrm{PGF}-2 \alpha$ concentration used for the Scatchard analysis, i.e. $16 \mathrm{nM}$ with or without $8 \mu \mathrm{M}-\mathrm{PGF}-2 \alpha$.

Table 2. Membrane preparations from ovariectomized rats treated with progesterone + oestradiol were incubated with $10 \mathrm{nM}-\left[{ }^{3} \mathrm{H}\right] \mathrm{PGF}-2 \alpha$ without $(100 \%$ binding) or with the competitor to be tested

\begin{tabular}{lcc}
\hline Competitor added & Dose & $\begin{array}{c}\left.{ }^{3} \mathrm{H}\right] \mathrm{PGF}-2 \alpha \text { binding } \\
\text { (\% of control) }\end{array}$ \\
\hline PGF-2 $\alpha$ & $10 \mathrm{nM}$ & $86.9 \pm 19.3$ \\
& $5 \mu \mathrm{M}$ & $41.7 \pm 5.6$ \\
PGE-2 & $10 \mathrm{nM}$ & $61.0 \pm 8.1$ \\
& $5 \mu \mathrm{M}$ & $56.8 \pm 10.5$ \\
$15-$ keto PGF-2 $\alpha$ & $10 \mathrm{nM}$ & $98.4 \pm 7.2$ \\
& $5 \mu \mathrm{M}$ & $71.7 \pm 6.9$ \\
Arachidonic acid & $10 \mathrm{nM}$ & $92.6 \pm 6.5$ \\
& $5 \mu \mathrm{M}$ & $71.4 \pm 1.6$ \\
\hline
\end{tabular}

Values are mean \pm s.e.m. for triplicate determinations.

preincubation with phospholipases. When trypsin inhibitor was added together with trypsin, no decrease in binding ability was observed $(101 \cdot 2 \%$ ). Heating the membrane preparation ( 3 min at $\left.100^{\circ} \mathrm{C}\right)$ also greatly reduced saturable binding of $\left[{ }^{3} \mathrm{H}\right] \mathrm{PGF}-2 \alpha(19 \cdot 7 \%)$.

\section{Specificity of the saturable $\left[{ }^{3} \mathrm{H}\right] P G F-2 a$ binding}

A membrane preparation from ovariectomized rats treated with progesterone + oestradiol was incubated with $10 \mathrm{nM}-\left[{ }^{3} \mathrm{H}\right] \mathrm{PGF}-2 \alpha$ without or with a low $(10 \mathrm{nM})$ or high $(5 \mu \mathrm{M})$ concentration of the competitor to be tested, after which $\left[{ }^{3} \mathrm{H}\right] \mathrm{PGF}-2 \alpha$ binding was measured. Table 2 shows that PGF-2 $\alpha$ and PGE-2 were both good competitors of $\left[{ }^{3} \mathrm{H}\right] \mathrm{PGF}-2 \alpha$ binding; the other prostaglandins, 15-keto PGF-2 $\alpha$, 15-keto PGE-2 and arachidonic acid, were poor competitors. The experiment was repeated several times and the same results were consistently found. 


\section{Metabolism of $\left[^{3} H\right] P G F-2 a$}

After incubation of $\left[{ }^{3} \mathrm{H}\right] \mathrm{PGF}-2 \alpha$ with membrane preparations from hormonally treated ovariectomized rats, all the solvent-extracted radioactivity cochromatographed with the $\left[{ }^{3} \mathrm{H}\right] \mathrm{PGF}-2 \alpha$ standards.

\section{Discussion}

This paper describes the failure to find $\left[{ }^{3} \mathrm{H}\right] \mathrm{PGF}-2 \alpha$ high-affinity binding sites in membrane preparations from rat endometrium sensitized for the decidual cell reaction. Identical results were obtained, regardless of the assay conditions in which $\mathrm{pH}$ was varied from 5 to 7 , thioglycerol was added to the buffer, or a higher PGF- $2 \alpha$ concentration was used. Similar results were also obtained using material from animals in different hormonal states: pseudopregnancy, or ovariectomized rats injected with progesterone and oestradiol, or with oestradiol alone.

Two lines of evidence suggest that our failure to detect PGF-2 $\alpha$ high-affinity binding sites in rat endometrium is not due to technical problems. First, using our experimental conditions, we were able to measure PGF- $2 \alpha$ binding in a membrane preparation from the ovaries of rats in late dioestrus or pro-oestrus. The PGF- $2 \alpha$ binding level, affinity and specificity were similar to those described by others (Wright et al., 1979; Müller et al., 1981) in the same experimental model. Secondly, we successfully detected high-affinity PGE-2 binding sites in the same endometrial preparations that did not exhibit high affinity PGF-2 $\alpha$ binding.

The possibility of $\left[{ }^{3} \mathrm{H}\right] \mathrm{PGF}-2 \alpha$ degradation during the incubation procedure was excluded by analysis of the $\left[{ }^{3} \mathrm{H}\right] \mathrm{PGF}-2 \alpha$ profile on thin-layer chromatography. It could be argued that we were unable to detect high-affinity PGF-2 $\alpha$ binding sites because these sites would be already occupied by endogenous prostaglandin and that the exchange of bound prostaglandin does not occur, or is slow in vitro. Against this hypothesis is the observation that no high-affinity PGF-2 $\alpha$ binding sites were detected in membrane preparations from rats injected subcutaneously with indomethacin, an inhibitor of prostaglandin synthesis (Vane, 1971), $2 \mathrm{~h}$ before being killed.

Taken together, the results of the present study suggest that the failure to detect high-affinity PGF- $2 \alpha$ binding sites in the endometrial membrane preparations of rats reflects a true absence of these binding sites. However, it is obvious from our results that saturable PGF- $2 \alpha$ binding, although low, does exist in these preparations. The level of this saturable binding cannot be determined from the Scatchard plots, but can be estimated from the highest [ $\left.{ }^{3} \mathrm{H}\right] \mathrm{PGF}-2 \alpha$ concentration used in the assay. The level of this saturable binding significantly increases on Day 5 of pseudopregnancy, passing from 17 to $35 \mathrm{fmol} / \mathrm{mg}$ membrane proteins. This increase coincides with the timing of uterine sensitivity for the decidual cell reaction, and with its ability to respond to prostaglandins (Kennedy \& Armstrong, 1981). This observation raises the possibility that PGF- $2 \alpha$ effects could be mediated through a receptor binding mechanism. Of importance is our finding concerning the specificity of this saturable binding: PGE-2 is as effective as PGF-2 $\alpha$ in competing with the $\left[{ }^{3} \mathrm{H}\right] \mathrm{PGF}-2 \alpha$ binding.

The $\left[{ }^{3} \mathrm{H}\right] \mathrm{PGF}-2 \alpha$ binding in endometrial preparations exhibits some of the criteria required for the establishment of a receptor: saturability and correlation with a biological effect, but does not fulfil all of these criteria, namely high affinity and specificity. Several types of interactions could account for this saturable $\left[{ }^{3} \mathrm{H}\right] \mathrm{PGF}-2 \alpha$ binding. Enzymes metabolizing PGs could contaminate the membrane preparations. A 15-hydroxyprostaglandin dehydrogenase activity has been shown to be present in human endometrium (Abel \& Kelly, 1983), the $K_{\mathrm{m}}$ for PGE-2 and PGF-2 $\alpha$ differs only by one order of magnitude $(1.89 \mu \mathrm{M}$ and $18.52 \mu \mathrm{M}$, respectively). Binding of the PG to enzymes is not necessarily inconsistent with the failure to detect metabolism; binding without metabolism may occur because of the absence of cofactors.

Kennedy et al. (1983a) showed that PGF-2 $\alpha$ possesses a weak affinity $\left(K_{\mathrm{d}} \simeq 1 \mu \mathrm{M}\right)$ for the endometrial PGE receptor. Our specificity experiment in the present study suggests that the $\left[{ }^{3} \mathrm{H}\right] \mathrm{PGF}-2 \alpha$ 
saturable binding could represent this cross-binding to the PGE receptor. The correlation we observed between the levels of $\left[{ }^{3} \mathrm{H}\right] \mathrm{PGF}-2 \alpha$ saturable binding and the biological effect would simply reflect the variations in binding sites for PGE-2 (Kennedy et al., 1983b). Furthermore, this could explain the puzzling observation that PGF- $2 \alpha$ had no effect on endometrial vascular permeability when injected as a bolus into the uterine lumen of sensitized rats, but slow uterine infusion resulted in increased vascular permeability (Kennedy \& Lukash, 1982) and decidualization (Hoffman et al., 1977). A PGF-2 $\alpha$ effect through an interaction with binding sites for PGE would require high PGF-2 $\alpha$ levels to saturate the binding sites. Our results are difficult to reconcile with those of Sananes et al. (1981), who described induction of decidualization in immature progesterone-treated rats, with the intraluminal injection of a low dose of PGF-2 $\alpha$. However, since no attempt was made to inhibit endogenous PG production in that study, the decidualization could have been caused by the exogenously administered PG, endogenously produced PGs, or by an interaction between exogenous and endogenous PGs.

The results described in the present paper are of importance since they suggest at least a partial answer to the question of which prostaglandin is involved in the implantation process. Although prostaglandins that exhibit vasoactive properties (PGE and PGI) would logically seem to be the mediators of the increased vascular permeability at implantation, PGF- $2 \alpha$ has been considered as a possible mediator in spite of its vasoconstrictive and luteolytic properties. The high levels of PGF-2 $\alpha$ measured in the implantation sites (Kennedy, 1977; Kennedy \& Zamecnik, 1978), or in the uterus after the application of a deciduogenic stimulus to a sensitized uterus (Rankin et al., 1979; Milligan \& Lytton, 1983), could simply reflect the local conversion of PGE-2 into PGF-2 $\alpha$ as shown in the rabbit uterus at the time of implantation (Cao, Jones \& Harper, 1984).

In conclusion, our results demonstrate the absence of a specific PGF- $2 \alpha$ receptor in endometrial membrane preparations from rats during the time of implantation. This, coupled with our previous work (Kennedy et al., 1983a, b), suggests that the prostaglandins of the E series, but probably not PGF- $2 \alpha$, are involved in blastocyst implantation in the rat.

Supported by the U.E.R. du Kremlin Bicêtre, Universite Paris-Sud (Grant No. 826) and the Institut National de la Santé et de la Recherche Médicale No. 834014.

\section{References}

Abel, H.M. \& Kelly, R.W. (1983) Metabolism of prostaglandins by the non pregnant human uterus. $J$. clin. Endocr. Metab. 56, 678-685.

Anteby, S.O., Bauminger, S., Zor, U. \& Lindner, H.R. (1975) Prostaglandin synthesis in decidual tissue of the rat uterus. Prostaglandins 10, 991-999.

Baird, D.T., Abel, M.H., Brown, A., Kelly, R.W. \& Wilmut, I. (1981) Synthesis and release of prostaglandins by the uterus during oestrous cycle and early pregnancy. In Utérus et Fécondité, pp. 69-82. Masson, S. A., Paris.

Castracane, V.D., Saksena, S.K. \& Shaikh, A.A. (1974) Effect of IUD's, prostaglandins and indomethacin on decidual cell reaction in the rat. Prostaglandins 6, $387-404$.

Cao, Z.D., Jones, M.A. \& Harper, M.J.K. (1984) Prostaglandin translocation from the lumen of the rabbit uterus in vitro in relation to day of pregnancy or pseudopregnancy. Biol. Reprod. 31, 305-319.

De Feo, V.C. (1966) Vaginal cervical vibration. A simple and effective method for the induction of pseudopregnancy in the rat. Endocrinology 79, 440-443.

De Feo, V.J. (1967) Decidualization. In Cellular Biology of the Uterus, pp. 191-290. Ed. R. M. Wynn. Plenum Press, New York.
Doebler, J.A., Wickersham, E.W. \& Anthony, A. (1981) Uterine prostaglandin F2 $\alpha$ content and $20 \alpha$ hydroxysteroid dehydrogenase activity of individual ovarian compartments during pseudopregnancy in the rat. Biol. Reprod. 24, 871-878.

El Banna, A.A. (1980) The degenerative effect on rabbit implantation sites by indomethacin. I. Timing of indomethacin action, possible effect on uterine proteins and the effect of replacement doses of PGF $2 \alpha$. Prostaglandins 20, 587-599.

Finn, C.A. (1977) The implantation reaction. In Biology of the Uterus, pp. 245-308. Ed. R. M. Wynn. Plenum Press, New York.

Hoffman, L.H., Strong, G.B., Davenport, G.R. \& Frölich, J.C. (1977) Deciduogenic effect of prostaglandin in the pseudopregnant rabbit. J. Reprod. Fert. 50, 231-237.

Hoffman, L.H., Davenport, G.R. \& Brash, A.R. (1984) Endometrial prostaglandins and phospholipase activity related to implantation in rabbits: effects of dexamethasone. Biol. Reprod. 30, 544-555.

Holmes, P.V. \& Gordashko, B.J. (1980) Evidence of prostaglandin involvement in blastocyst implantation. J. Embryol. exp. Morph. 55, 109-122. 
Kennedy, T.G. (1977) Evidence for a role for prostaglandins in the initiation of blastocyst implantation in the rat. Biol. Reprod. 16, 286-291.

Kennedy, T.G. (1979) Prostaglandins and increased endometrial vascular permeability resulting from the application of an artificial stimulus to the uterus of the rat sensitized for the decidual cell reaction. Biol. Reprod. 20, 560-566.

Kennedy, T.G. \& Armstrong, D.T. (1981) The role of prostaglandins in endometrial vascular changes at implantation. In Cellular and Molecular Aspects of Implantation, pp. 349-363. Eds S. R. Glasser \& D. W. Bullock. Plenum Press, New York.

Kennedy, T.G. \& Lukash, L.A. (1982) Induction of decidualization in rats by the intrauterine infusion of prostaglandins. Biol. Reprod. 27, 253-260.

Kennedy, T.G. \& Zamecnik, J. (1978) The concentration of 6-ketoprostaglandin Fla is markedly elevated at the site of blastocyst implantation in the rat. Prostaglandins 16, 599-605.

Kennedy, T.G., Barke, G.J. \& Evans, C.A. (1980) Prostaglandin 12 and increased endometrial vascular permeability preceding the decidual cell reaction. In The Endometrium, pp. 331-341. Ed. F. A. Kimbal. Spectrum Publications, New York.

Kennedy, T.G., Martel, D. \& Psychoyos, A. (1983a) Endometrial prostaglandin E2 binding: characterization in rats sensitized for the decidual cell reaction and changes during pseudopregnancy. Biol. Reprod. 29, 556-564.

Kennedy, T.G., Martel, D. \& Psychoyos, A. (1983b) Endometrial prostaglandin E2 binding during the estrous cycle and its hormonal control in ovariectomized rats. Biol. Reprod. 29, 565-571.

Lau, I.F., Saksena, S.K. \& Chang, M.C. (1973) Pregnancy blockade by indomethacin an inhibitor of prostaglandin synthesis: its reversal by prostaglandins and progesterone in mice. Prostaglandins 4, 795-803.

Lowry, O.H., Rosebrough, N.J., Farr, A.L. \& Randall, R.J. (1951) Protein measurement with the Folin phenol reagent. J. biol. Chem. 193, 265-275.

Lundkvist, O. \& Nilsson, B.O. (1980) Ultrastructural changes of the trophoblast-epithelial complex in mice subjected to implantation blocking treatment with indomethacin. Biol. Reprod. 22, 719-726.

Martel, D. \& Psychoyos, A. (1978) Progesterone induced oestrogen receptors in the rat uterus. J. Endocr. 76, 145-154.

Milligan, S.R. \& Lytton, F.D.C. (1983) Changes in prostaglandin levels in the sensitized and non sensitized uterus of the mouse after the intrauterine instillation of oil or saline. J. Reprod. Fert. 67, 373-377.

Müller, U., Bauknecht, T. \& Siebers, J. (1981) Development and regulation of the prostaglandin $F 2 \alpha$ receptor in rat ovary. Acta endocr., Copenh. 98 , 441-445.
Oettel, M., Koch, M., Kurischko, A. \& Schubert, K. (1979) A direct evidence for the involvement of prostaglandin F2 $\alpha$ in the first step of estrone induced blastocyst implantation in the spayed rat. Steroids 33, 2287-2351.

Phillips, C.A. \& Poyser, N.L. (1981) Studies on the involvement of prostaglandins in implantation in the rat. J. Reprod. Fert. 62, 73-81.

Psychoyos, A. (1960) Nouvelles contributions à l'étude de la nidation de l'oeuf chez la ratte. $C$. $r$. hebd. Séanc. Acad. Sci., Paris D 251, 3073-3075.

Psychoyos, A. (1967) The hormonal interplay controlling egg-implantation in the rat. In Advances in Reproductive Physiology, pp. 257-277. Ed. A. McLaren. Logos Press, London.

Psychoyos, A. (1973) Hormonal control of ovoimplantation. Vitams Horm. 31, 201-256.

Rankin, J.C., Ledfort, B.E., Jonsson, H.T., Jr \& Baggett, B. (1979) Prostaglandins, indomethacin and the decidual cell reaction in the mouse uterus. Biol. Reprod. 20, 399-404.

Rao, C. (1976) Properties of prostaglandin F2 $\alpha$ receptors in bovine corpus luteum membranes. Molec. cell. Endocr. 6, 1-16.

Saksena, S.K., Lau, I.F. \& Chang, M.C. (1976) Relationship between oestrogen, prostaglandin $F 2 \alpha$ and histamine in delayed implantation in the mouse. Acta endocr., Copenh. 42, 225-232.

Sananes, N., Baulieu, E.E. \& Le Goascogne, C. (1976) Prostaglandin(s) as inductive factor of decidualization in the rat uterus. Molec. cell. Endocr. 6, 153-158.

Sananes, N., Baulieu, E.E. \& Le Goascogne, C. (1981) A role for prostaglandins in decidualization in the rat uterus. J. Endocr. 89, 25-33.

Scatchard, G. (1949) The attraction of proteins for small molecules and ions. Ann. N.Y. Acad. Sci. 51, 660672

Tobert, J.A. (1976) A study of the possible role of prostaglandins in decidualization using a non-surgical method for the instillation of fluids into the rat uterine lumen. J. Reprod. Fert. 47, 391-393.

Vane, J.R. (1971) Inhibition of prostaglandin synthesis as a mechanism of action of aspirine-like drugs. Nature, New Biol. 231, 232-235.

Weems, C.W. (1979) Prostaglandins $F$ in uterine and ovarian compartments and in plasma from the uterine vein, ovarian artery and vein, and abdominal aorta of pseudopregnant rats with and without deciduomata. Prostaglandins 17, 873-890.

Wright, K., Luborsky-Moore, J.R. \& Behrman, H.R. (1979) Specific binding of prostaglandin F2 $\alpha$ to membranes of rat corpora lutea. Molec. cell. Endocr. 13, 25-34.

Yochim, J.M. \& De Feo, V.J. (1963) Hormonal control of the onset, magnitude and duration of uterine sensitivity in the rat by steroid hormones of the ovary. Endocrinology 72, 317-326.

Received 1 February 1985 